\title{
The Right Not to Sue: A First Amendment Rationale for Opting Out of Mandatory Class Actions
}

\author{
Maximilian A. Grant $\dagger$
}

[F]ree speech and fair trials are two of the most cherished policies of our civilization, and it would be a trying task to choose between them. ${ }^{1}$

Justice Hugo Black

Mandatory class actions-those for which no right to opt out exists ${ }^{2}$-are unique in the law. They define the rights and duties of absent parties through compelled participation and inextricably join the interests of class members toward a common end. As the incidence and importance of class actions multiply, so should concerns about them. Class actions are being used with increasing frequency by litigants, and they have become a powerful device for relieving overloaded judicial dockets. ${ }^{3}$ As a result, a potential conflict arises between the judiciary's interest in handling a burdensome caseload efficiently and the individual interests of persons who would prefer to assert their legal rights independently, or not at all.

Until now, the Due Process Clause has provided the sole analytic framework for courts considering class actions in constitutional terms. In fact, the Supreme Court has indicated an interest in considering the scope of the opt-out right under a due process analysis, ${ }^{4}$ although it has not yet heard a case on point.

$\dagger$ B.S. 1988, United States Naval Academy; M.A. 1989, Georgetown University; J.D. Candidate 1996, The University of Chicago.

1 Bridges v California, 314 US 252, 260 (1941).

2 See text accompanying notes 10-12.

3 See, for example, Arthur R. Miller and David Crump, Jurisdiction and Choice of Law in Multistate Class Actions After Phillips Petroleum Co. v. Shutts, 96 Yale L J 1, 4 (1986) ("[S]ophisticated litigation management techniques made courts and lawyers more disposed to regard the class action as an efficient vehicle for resolving disputes.") (citations omitted).

4 See Ticor Title Insurance Co. v Brown, 114 S Ct 56 (1993) (granting cert). Certiorari was later dismissed as improvidently granted over the objection of three Justices. 114 S Ct 1359, 1362 (1994) (O’Connor dissenting). 
To date, however, the due process-based analysis of class actions has produced doctrinal confusion about the scope of the right to opt out and inconsistent rulings from lower courts. ${ }^{5}$ Additionally, this analysis ignores important constitutional interests implicated by existing law.

A solution lies in the First Amendment. ${ }^{6}$ Supreme Court jurisprudence makes it impossible to ignore both a legitimate basis for, and challenge to, the class action device derived from the freedoms of expression and association. Grounding the class action device on First Amendment jurisprudence would strengthen it by providing a surer doctrinal foundation. ${ }^{7}$ However, the implication of a First Amendment basis for class actions is a corresponding right to opt out. By requiring participation of absent class members in litigation, a constitutionally protected form of expression and association, mandatory class actions are inconsistent with established First Amendment doctrine. This Comment argues that because the rights of expression and association include both the right to act and the right to refrain, mandatory participation in a class action constitutes compelled expression and association in violation of the First Amendment.

Section I explains the prevailing due process-based treatment of the right to opt out. It finds the current state of the law confused and the scope of the opt-out right undefined. Section II argues that the freedoms of expression and association provide an alternative constitutional foundation for the right to opt out and that First Amendment jurisprudence conflicts with the very nature of mandatory class actions. Section III sets out the First Amendment interests implicated by mandatory class actions and draws three conclusions: first, that restrictions on the right to opt out are not content neutral as applied; second, that state interests do not preclude judicial review of the statutorily created class action device; and third, that individual interests in opting out vary depending on the goals of the class action. It then divides the First Amendment-based right to opt out into two categories, political and commercial, defined by the goals of the suit.

5 See note 36.

6 "Congress shall make no law respecting an establishment of religion, or prohibiting the free exercise thereof; or abridging the freedom of speech, or of the press; or the right of the people peaceably to assemble, and to petition the Government for a redress of grievances." US Const, Amend I.

7 See John Leubsdorf, Constitutional Civil Procedure, 63 Tex L Rev 579, 579-80, 61620 (1984) (suggesting that the freedom to associate and bring grievances to the courts provides a superior constitutional basis for class actions than does due process). 
Section IV analyzes the First Amendment interests at stake in these cases and argues for the application of strict scrutiny to "political" class actions and intermediate scrutiny to "commercial" class actions. This Section then proposes a more narrowly drawn alternative to existing practice for each category.

The Comment concludes that the application of First Amendment jurisprudence to the opt-out problem has two results. First, it requires courts to recognize a heretofore unrecognized right to opt out of political mandatory class actions. Second, it bolsters an existing due process-based analysis by finding an opt-out right in commercial mandatory class actions when the suit no longer pursues the original goals or legal remedies for which the class was certified.

\section{The State OF THE LAW: UNDERSTANDING THE DUE PROCESS MESS}

The current due process paradigm courts use to examine the opt-out right fails to account for all of the competing interests at stake. As a result, the scope of the right to opt out is unclear, and lower court decisions reflect this confusion. Indeed, the Supreme Court has addressed the scope of the opt-out right only once, this in a limited holding that did little to clarify, and in fact further confused, the situation. ${ }^{9}$

Class actions, and the prerequisites for certification, are defined by Federal Rule of Civil Procedure 23. The rule divides class actions into categories based on Rule 23's three subdivisions. ${ }^{10}$ By the Rule's express provisions, only subdivision (b)(3)

* See, for example, notes 19, 24-26.

${ }^{9}$ See Phillips Petroleum Co. $v$ Shutts, 472 US 797 (1985). See also text accompanying notes 27-36.

10 Rule 23, entitled "Class Actions," was rewritten in 1966 to require four prerequisites to all class actions: the so-called "numerosity," "commonality," "typicality," and "adequacy of representation" requirements. In addition, a class action must also meet the requirements of one of Rule 23(b)'s three subparts; that is, it must satisfy the standards of either Rule 23(b)(1), which requires that, in the absence of a class action, separate actions would (A) establish incompatible standards of conduct for the party opposing the class, or (B) practically prejudice the interests of class members not made parties; or Rule 23(b)(2), which requires that injunctive or declaratory relief would be appropriate with respect to the class as a whole; or Rule 23(b)(3), which requires that common questions predominate the dispute and that the class action is superior to other available methods for the fair and efficient adjudication of the controversy. In class actions maintained under Rule 23(b)(3), Rule 23(c)(2) requires that class members be given notice and the right to opt out. See note 11. Rule 23 (c)(3), which governs class actions maintained under Rule 23(b)(1) or (b)(2), has no such requirement. See note 12. See also FRCP 23, Advisory Committee Notes to 1966 Amendment. 
requires that absent class members receive notice of a suit and an opportunity to return a "request for exclusion," or opt-out, form. ${ }^{11}$ Thus, subdivision (b)(3) class actions may be termed "permissive." By contrast, Rule 23 contains no provisions for notice or opting out in class actions maintained under subdivisions (b)(1) and (b)(2);12 as such, these actions may be termed "mandatory."

Rule 23 directs courts to determine "as soon as practicable" whether class certification is appropriate..$^{13}$ Although an evidentiary hearing on the issue of certification is not required, a denial of class action certification should not ordinarily be made without giving the plaintiffs an evidentiary opportunity, if requested. ${ }^{14}$ Courts have wide discretion in certifying class actions. However, where suits meet the requirements of both mandatory and permissive class actions, courts usually favor certification as mandatory. ${ }^{15}$

Proponents asserting the statutory existence of mandatory class certification claim support from the "absence of express notice or opt-out provisions" in Rule 23 , and from the "implicit preference for unitary adjudication that underlies subdivisions (b)(1) and (b)(2)."16 Considerations of judicial consistency, efficiency, leverage for settlements, and access for small claims encourage plaintiffs to seek mandatory certification. ${ }^{17}$ Defendants may also benefit from the convenience and efficiency of having all claims against them resolved in unitary proceedings and from

11 "In any class action maintained under subdivision (b)(3), the court shall direct to the members of the class the best notice practicable under the circumstances, including individual notice to all members who can be identified through reasonable effort. The notice shall advise each member that $(A)$ the court will exclude the member from the class if the member so requests by a specified date; (B) the judgment, whether favorable or not, will include all members who do not request exclusion. ..." FRCP 23(c)(2).

${ }_{12}$ "The judgment in an action maintained as a class action under subdivision (b)(1) or (b)(2), whether or not favorable to the class, shall include and describe those whom the court finds to be members of the class." FRCP 23(c)(3).

${ }^{13}$ FRCP 23(c)(1). A request for certification is made on motion from a party, often a plaintiff.

${ }^{14}$ Sam C. Pointer, et al, Manual for Complex Litigation $\$ 30.13$ at 216-17 (CCH 3d ed 1995). See also Marcera $v$ Chinlund, 565 F2d 253, 255 (2d Cir 1977), judgment vacated by Lombard $v$ Marcera, 442 US 915 (1979) (holding that trial court erred in denying class certification without a hearing).

${ }^{25}$ See text accompanying notes 133-34.

16 Miller and Crump, 96 Yale L J at 38 (cited in note 3).

17 Id at 39. 
reduced exposure to multiple liabilities, particularly for punitive damages. ${ }^{18}$

Nevertheless, policy considerations such as distributional fairness, convenience, and efficiency do not insulate Rule 23 from constitutional scrutiny. ${ }^{19}$ Mandatory class actions are an exception to the historical "principle of general application in AngloAmerican jurisprudence that one is not bound by a judgment in personam in a litigation in which he is not designated as a party or to which he had not been made a party by service of process." ${ }^{20}$ Moreover, before a general revision of equity rules in 1912, even a judgment in a class action could not bind absent class members. ${ }^{21}$ In 1976, the Supreme Court established a balancing test for due process claims in which a party asserted deprivation of a property interest without a judicial hearing. ${ }^{22}$ The Court's balancing test seems to confirm the historical rule that absent class members could not be bound by judgments except for purely injunctive or declaratory relief..$^{23}$

As courts have adjudicated cases concerning the right to opt out of mandatory class actions, considerations of individual due process have collided with policies favoring the device. The predictable result has been confusion in the lower courts. For example, before 1985, there was a clear split of authority concerning the scope of the opt-out right. On one side, a majority of the appellate circuits held that there was no constitutional infirmity in the lack of an opt-out provision for classes certified under Rule 23(b)(2). ${ }^{24}$ By contrast, the minority view, forwarded by the Fifth

18 Id.

19 Some authorities have noted constitutional concerns inherent in mandatory class actions. See, for example, id (stating that for absent class members without minimum contacts in the forum state, "[t]here can be no mandatory class if the members have the constitutional right to opt out"); In re A.H. Robins Co., 880 F2d 709, 744-45 (4th Cir 1989), quoting Mark C. Weber, Preclusion and Procedural Due Process in Rule 23(b)(2) Class Actions, 21 U Mich J Legal Ref 347, 394 (1988) ("The problem of the Rule 23(b)(2) class action is that binding absent class members without giving them notice and the right to opt out violates due process."); DeGier $v$ McDonald's Corp, 76 FRD 125, 127 (N D Cal 1977) (holding that equal protection and due process require the right to opt out of Rule 23(b)(2) classes because there is no logical distinction between denial of access to a trial court and mandatory inclusion in a class action before a trial court).

20 Hansberry $v$ Lee, 311 US 32, 40 (1940).

21 See Stephen C. Yeazell, From Group Litigation to Class Action Part II: Interest, Class and Representation, 27 UCLA L Rev 1067, 1096 (1980); Supreme Tribe of Ben-Hur v Cauble, 255 US 356, 366-67 (1921).

22 Mathews $v$ Eldridge, 424 US 319, 334-35 (1976).

23 See Charles Alan Wright, Arthur R. Miller, and Mary Kay Kane, 7A Federal Practice and Procedure $\$ 1751$ at 10 (West $2 d$ ed 1986).

24 See, for example, Laskey $v U A W, 638$ F2d 954, 956-57 (6th Cir 1981) ("[F]ailure to 
and Eleventh Circuits, acknowledged that where a monetary aspect of injunctive relief exists, the interests of individual class members are likely to diverge. ${ }^{25}$ In such "hybrid" suits (seeking both injunctive and monetary relief), these courts bifurcated the proceedings for plaintiffs, creating a (b)(2) class for the injunctive relief and a (b)(3) class for the monetary relief. But the fact that both sides to this disagreement justified their conclusions under a due process analysis ${ }^{26}$ shows the inherent indeterminacy and inadequacy of the Due Process Clause as a tool for balancing class and individual interests. This suggests that due process may be too manipulable a framework to provide a solid analytical foundation for approaching either class actions or the right to opt out.

The Supreme Court's use of the due process framework has further confused the debate. In Phillips Petroleum Co. $v$ Shutts, the Supreme Court considered a complex case where some twenty-eight thousand royalty owners possessed rights to leases from which Phillips produced natural gas. ${ }^{27}$ The class of owners, which included residents of all fifty states, Washington D.C., and several foreign countries, filed suit in Kansas state court to recover interest on delayed royalty payments owed to them by Phillips. ${ }^{28}$ The Court addressed whether a forum state could bind absent plaintiffs in a class action asserting claims "wholly or predominantly for money judgments."29 This was, and remains,

notify $[(b)(2)]$ class members of the right to opt out of the class is not a violation of due process."); Bauman v United States District Court, 557 F2d 650, 659-60 (9th Cir 1977) (noting absence of Supreme Court authority and circuit split on issue).

${ }_{25}$ See, for example, Holmes $v$ Continental Can Co., 706 F2d 1144, 1160 (11th Cir 1983) (holding that district court abused its discretion in refusing to provide opt-out procedure in (b)(2) class action); Johnson v General Motors Corp, 598 F2d 432, 437 (5th Cir 1979) (holding that where absent class member received no notice of (b)(2) action, judgment in class action suit did not preclude subsequent suit for monetary damages). Compare Scott $v$ City of Anniston, 682 F2d 1353, 1358 (11th Cir 1982), quoting Wetzel $v$ Liberty Mutual Insurance Co., 508 F2d 239, 251 (3d Cir 1975) (holding that, in (b)(2) class action seeking equitable and monetary relief, suit needed not be reclassified under (b)(3) after equitable issues dropped out of case, so long as "cohesive characteristics of the class" were still intact). In such "hybrid" suits, these courts felt, subsection (b)(2)'s underlying assumption-a homogenous class without conflicting interests among class members-may not be valid. See, for example, id at 256.

${ }^{26}$ Compare Laskey, 638 F2d at 956-57 ("[F]ailure to notify [(b)(2)] class members of the right to opt out of the class is not a violation of due process."), with Johnson, 598 F2d at 438 ("Before an absent class member may be forever barred from pursuing an individual damage claim ... due process requires that he receive some form of notice that the class action is pending and that his damage claims may be adjudicated as part of it.").

${ }^{27} 472$ US 797, 800-02 (1985).

${ }^{28}$ Id at 799.

29 Id at $802,811 \mathrm{n} 3$. 
the only time that the Court has addressed the constitutionality of mandatory class actions.

The Shutts Court held that minimum due process requires that absent plaintiffs receive notice and an opportunity to opt out, even if a court certifies the class as mandatory. ${ }^{30}$ The Court specifically limited its holding to claims "wholly or predominantly for money judgments" and expressly stated no opinion as to "other types of class actions." ${ }^{.31}$ Nevertheless, by characterizing the opt-out right as a "minimal procedural due process"32 requirement, the Court's decision appears at odds with Rule 23's mandatory class action device. ${ }^{33}$

Because the rationale behind the Court's money damages-based distinction remains unclear, Shutts may have raised more questions than it answered. ${ }^{34}$ Some commentators have questioned whether mandatory class actions survive the decision at all..$^{35}$ At the very least, Shutts left uncertain the scope of the opt-out right it recognized. For example, it failed to address whether absent class members must be given an opportunity to opt out of a class action seeking injunctive relief with a monetary component, such as back pay. The post-Shutts void is especially troublesome when seen against a statutory and doctrinal background that equally fails to define precisely the boundaries of the opt-out right. ${ }^{36}$

In short, Shutts took a confused area of the law and did little with it. However, the doctrinal void may be more attributable to the lack of rigor inherent in the due process framework than to the Court's intentionally narrow holding. Nevertheless, Shutts at

30 Id at 811.

31 Id at $811 \mathrm{n} 3$.

${ }_{32}$ Id at 811-12.

33 See Miller and Crump, 96 Yale $\mathrm{L} J$ at 39 (cited in note 3 ).

34 Id at 7.

35. See, for example, id at 54.

See, for example, Mark W. Friedman, Note, Constrained Individualism in Group Litigation: Requiring Class Members to Make a Good Cause Showing Before Opting Out of a Federal Class Action, 100 Yale L J 745, 749 (1990) ("[T]he constitutional and philosophical underpinnings of the right to opt out are so ambiguous that before Shutts lower courts divided over whether any such constitutional right even existed."). Compare Dosier $v$ Miami Valley Broadcasting Corp, 656 F2d 1295, 1299 (9th Cir 1981) (holding that there is no due process right for unnamed plaintiffs to opt out of (b)(2) class actions); Kincade $v$ General Tire and Rubber Co., 635 F2d 501, 506-07 (5th Cir 1981) (suggesting opt-out right is statutory, not constitutional); Allen $v$ Isaac, 100 FRD 373, 377 (N D Ill 1983) (holding due process rights of class members best protected by permitting opt out of (b)(2) class); DeGier, 76 FRD at 127 (holding that equal protection and due process require the right to opt out of Rule 23(b)(2) classes because there is "no logical distinction between denial of access to a trial court and mandatory inclusion in a class action before a trial court"). 
least focused the continuing debate, as commentators and courts alike have since considered the opt-out question solely within the due process framework. The decision's inability to forge a consensus on whether the Due Process Clause requires a right to opt out of (b)(2) class actions evinces continuing confusion in this area. ${ }^{37}$ This is because the assumption, often offered to justify the lack of an opt-out right, that (b)(2) class actions seeking solely injunctive relief are sufficiently cohesive to require mandatory participation may prove invalid in certain situations. For example, where a class action seeks equitable relief in pursuit of political or ideological goals, class cohesion cannot be presumed. The continuing confusion in the lower courts further demonstrates the inadequacy of the due process framework as a solution to this problem. Thus, the important, unanswered question remains: What is the scope of the right to opt out in class actions not covered by Shutts-that is, those not "wholly or predominantly" for money damages? ${ }^{38}$

Moreover, this issue is ripe for adjudication. A recent case suggests that the Supreme Court is prepared to consider whether absent class members have a constitutional due process right to opt out of mandatory class actions asserting monetary claims on their behalf. ${ }^{39}$ Also, many commentators and courts have openly questioned when a mandatory class action is consistent with the Constitution without an associated right to opt out. ${ }^{40}$ None, however, has examined the issue from a First Amendment perspective.

The Supreme Court's possible willingness to address this issue provides an ideal opportunity to establish the constitutional

${ }^{37}$ See, for example, Besinga $v$ United States, 923 F2d 133, 137 n 7 (9th Cir 1991), cert denied, $115 \mathrm{~S}$ Ct 180 (1994) (stating due process rights of absent members of (b)(2) class are generally satisfied without an opt-out right), citing Johnson, 598 F2d at 437-38; In re Temple, 851 F2d 1269, 1272 n 5 (11th Cir 1988) (stating that absent class members may have a right to opt out of mandatory class action where the predominant issue is money damages).

${ }^{33}$ See Shutts, 472 US at $811 \mathrm{n} 3$.

${ }^{39}$ See Ticor Title Insurance Co. $v$ Brown, 114 S Ct 56 (1993) (granting cert), cert dismissed as improvidently granted, 114 S Ct 1359, 1361 (1994) (reviewing "whether a federal court may refuse to enforce a prior federal class action judgment, properly certified under Rule 23, on grounds that absent class members have a constitutional due process right to opt out of any class action which asserts monetary claims on their behalf"). Three Justices dissented from dismissal of certiorari, arguing that, notwithstanding that the class may not have been properly certified as a (b)(2) action, the substantive issue of the opt-out right had been joined and was ripe for resolution. Id at 1364 (O'Connor, joined by Kennedy and Rehnquist, dissenting).

40 See note 19. 
basis for class actions and the scope of a right to opt out. Indeed, the duty to say where the individual's freedom ends and the state's power begins ultimately belongs to the Supreme Court. ${ }^{41}$ The right to opt out is regulated in the public interest; nevertheless, if that regulation results in an indirect, conditional, or partial abridgment of First Amendment rights-as suggested below-then it is the Court's duty to determine which of the two conflicting interests demands preferred protection. ${ }^{42}$

\section{Constitutional Foundations For A FiRST AMENDMENT RIGHT TO OPT OUT}

Two factors compel the recognition of a First Amendment right to opt out of mandatory class actions. First, the right to opt out is the logical concomitant of three rights recognized by the Supreme Court as protected by the First Amendment: the right to associate in groups, the right to engage in litigation as expression, and the right to refrain from expression and association. Second, failure to recognize an opt-out right results in compelled expression and association directly analogous to that proscribed by established First Amendment precedent.

It is essential to note that although the class action device is a unique litigation tool, nothing excepts it from the requirements and prohibitions of the First Amendment. For example, in Bernard $v$ Gulf Oil Co., the Fifth Circuit considered the propriety of a prior restraint limiting communications between existing class representatives and potential class members, and held that such a restraint would be unconstitutional unless the communication posed a "clear and present danger or a reasonable likelihood of a serious and imminent threat to the administration of justice." ${ }^{* 3}$ The court stated:

[A] court's discretion under Rule 23 is a facet of its general authority to regulate the conduct of litigation. To the extent that Rule 23 implements the class action as a unique litigation device, that discretion may be correspondingly broadened, and we recognize broad management powers of the court under Rule 23. But, while a legislative enactment may

41 See Thomas $v$ Collins, 323 US 516, 529-31 (1945) ("[I]n our system where the line can constitutionally be placed presents a question this Court cannot escape answering independently.").

${ }^{42}$ See American Communications Association v Douds, 339 US 382, 399 (1950).

43619 F2d 459, 475 (5th Cir 1980), aff'd, 452 US 89 (1981), quoting Rodgers $v$ United States Steel Corp, 536 F2d 1001, 1008 (3d Cir 1976). 
alter the court's authority under common law, it may not encroach upon constitutionally protected rights. ${ }^{44}$

Citing the Rules Enabling Act, the court noted that procedural rules "shall not abridge, enlarge or modify any substantive right." "The idea that class actions inherently provide an exception to established First Amendment jurisprudence was rejected. ${ }^{46}$

\section{A. First Amendment Predicates of the Right to Opt Out}

The right to opt out of class actions is a necessary corollary of three First Amendment rights already recognized by the Supreme Court, specifically the rights of individuals to associate in groups, to engage in litigation as expression, and to refrain from expression and association. ${ }^{47}$ In combination, these rights form the basis of a First Amendment right to opt out of class actions.

An independent right to engage in association for the advancement of beliefs and ideas was first explicitly recognized in 1958. In NAACP $v$ Patterson, the Supreme Court held that this right was derived from First Amendment guarantees of speech, press, assembly, and petition. ${ }^{48}$ The opinion implicitly bifurcated the right of association into individual and collective components, ${ }^{49}$ and the Court explicitly recognized this separation in Roberts $v$ United States Jaycees. ${ }^{50}$ The individual component protects intimate human relationships as an essential element of fundamental personal liberty. ${ }^{51}$ The collective component protects association for the purpose of engaging in those activities

44 Bernard, 619 F2d at 475.

45 Id, quoting 28 USC § 2072 (1966).

${ }^{46}$ Bernard, $619 \mathrm{~F} 2 \mathrm{~d}$ at 475 ("We cannot interpret Rule 23 as authorizing prior restraints without rewriting the First Amendment and the gloss put upon it by the Supreme Court.").

${ }^{47}$ Smith v Arkansas State Highway Employees, Local 1315, 441 US 463, 464 (1979) ("The First Amendment protects the right of an individual to speak freely, to advocate ideas, to associate with others, and to petition his government for redress of grievances."); NAACP v Button, 371 US 415, 429 (1963) (noting that, in the context of NAACP objectives, litigation is a form of protected expression); Pacific Gas \& Electric Co. $v$ Public Utilities Commission of California, 475 US 1, 16 (1986) (holding that "the choice to speak includes within it the choice of what not to say"). See also text accompanying notes 48-65.

48357 US 449, 460-63 (1958).

49 Id at 462. See also Republican Party v Tashjian, 770 F2d 265, 276-77 (2d Cir 1985), aff'dm 479 US 208 (1986).

50 468 US 609, 617-18 (1984).

s1 Id at 618 . 
independently protected by the First Amendment as an "indispensable means of preserving other individual liberties. 352

Five years after it decided Patterson, the Court held in NAACP $v$ Button that certain NAACP activities-essentially, the solicitation of litigation-were "modes of expression and association" constitutionally protected by the First and Fourteenth Amendments. ${ }^{53}$ The Court held that vigorous advocacy of lawful ends is protected by the First Amendment, and recognized that, in the context of NAACP objectives, litigation is a form of political expression. ${ }^{54}$

Just as it was true of the opponents of New Deal legislation during the 1930's, for example, no less is true of the [African-American] minority today. And under the conditions of modern government, litigation may well be the sole practicable avenue open to a minority to petition for redress of grievances. ${ }^{55}$

Thus, Button established that where litigation is a vehicle for political expression, it is entitled to the full constitutional protection afforded by the First Amendment. ${ }^{56}$

Where litigation is defined as a form of protected expression, association in pursuit of litigation must be similarly protected. ${ }^{57}$ Indeed, in United Transportation Union v State Bar, the Court

52. Id (holding that association in pursuit of speech, assembly, and petition for the redress of grievances is protected).

5331 US 415, 428-29 (1963). See also In re Primus, 436 US 412, 431 (1978) (characterizing ACLU participation in litigation as a "vehicle for effective political expression and association, as well as a means of communicating useful information to the public").

54 Button, 371 US at 428-29. See also Brotherhood of Railroad Trainmen $v$ Virginia, 377 US 1, 5-6 (1964) (holding that First Amendment rights of free speech, petition, and assembly give railroad workers the right to gather together to assist each other in asserting their rights under federal statutes).

Bs Button, 371 US at 429-30.

cs See also In re Primus, 436 US at 428 , quoting Button, 371 US at 429,431 ("For the ACLU, as for the NAACP, Titigation is . . a form of political expression' and 'political association."); Rizzo v Dawson, 778 F2d 527, 531-32 (9th Cir 1985) (assisting another person in litigation is a form of expression and association protected by the First Amendment); Professional Real Estate Investors, Inc. v Columbia Pictures Indus., Inc., $113 \mathrm{~S} \mathrm{Ct}$ 1920,1923 (1993) (stating that under Noerr-Pennington doctrine, participation in judicial and administrative proceedings is protected by the First Amendment unless it is "objectively baseless").

${ }^{67}$ See Button, 371 US at 431 ("For [some] group[s], association for litigation may be the most effective form of political association."); Tashjian, 770 F2d at 276-79 ("Freedom of association confers a right to join with others to pursue activities independently protected by the first amendment."). See also Eilers v Palmer, 575 F Supp 1259, 1261 (D Minn 1984), citing Button, 371 US at 428-29 ("[S]upport of litigation is a form of expression and association protected by the first amendment."). 
confirmed that collective activity undertaken to obtain "meaningful access" to the courts was a fundamental right under the First Amendment-the Court called this the "basic right to group legal action." ${ }^{.58}$ Agreeing that freedom of expression and association may include litigation, Justice Harlan's dissent (on other grounds) in Button succinctly stated the majority's position:

Freedom of expression embraces more than the right of an individual to speak his mind. It includes also his right to advocate and his right to join with his fellows in an effort to make that advocacy effective. And just as it includes the right jointly to petition the legislature for redress of grievances, so it must include the right to join together for purposes of obtaining judicial redress. ${ }^{59}$

Indeed, "[a]n individual's freedom to speak ... and to petition the government for the redress of grievances could not be vigorously protected from interference by the State unless a correlative freedom to engage in group effort toward those ends were not also guaranteed."

The Court has also ruled more recently that litigation in support of civil liberties is constitutionally protected political expression and association. ${ }^{61}$ In so doing, the Court stated:

Button recognized that certain forms of cooperative, organizational activity, including litigation, are part of the freedom to engage in association for the advancement of beliefs and ideas, and that this freedom is an implicit guarantee of the First Amendment. ${ }^{62}$

ss 401 US 576, 585 (1971). See also Primus, 436 US at 426 . The Court has also held that "[f]ree trade in ideas' means free trade in the opportunity to persuade to action, not merely to describe facts." Button, 371 US at 437, quoting Thomas $v$ Collins, 323 US 516, 537 (1945).

59 Button, 371 US at 452-53 (Harlan dissenting) (citations omitted).

${ }^{60}$ Roberts, 468 US at 622.

${ }^{61}$ Primus, 436 US at 427-29, citing Button, 371 US at $429,431$.

${ }_{62}$ Primus, 436 US at $438 \mathrm{n} 32$ (citations omitted). The right to associate for litigation is considered especially important where the rights of minority groups are at issue. See Patterson, 357 US at 462 ("Inviolability of privacy in group association may in many circumstances be indispensable to preservation of freedom of association, particularly where a group espouses dissident beliefs."); Button, 371 US at 431 (stating that for a group such as the NAACP, "association for litigation may be the most effective form of political association"). Compare Sweezy v New Hampshire, 354 US 234, 250-51 (1957) (plurality opinion) (stating "[h]istory has aptly proved the virtue of political activity by minority, dissident groups, who innumerable times have been in the vanguard of democratic thought and whose programs were ultimately accepted"). 
While the First Amendment protects free expression and association, it also protects the choice to refrain from either activity. The First Amendment protects both the right to speak freely and the right to remain silent. ${ }^{63}$ In essence, the right to speak and the right to refrain from speaking are "complementary components" of the broader First Amendment concept of "individual freedom of mind." ${ }^{164}$ Similarly, freedom of association "plainly presupposes a freedom not to associate." ${ }^{\text {"5 }}$ Thus, given that there is a constitutional right to associate for the purpose of pursuing litigation, a complementary right to remove oneself from such an association must also exist.

\section{B. Mandatory Class Actions Compel Expression and Association in Violation of the First Amendment}

Since an individual has a right of "nonassociation," it follows that compelled association must violate that right. Individuals cannot be forced to associate with or to support, financially or otherwise, expressive activities with which they disagree. ${ }^{66}$ In her concurrence in Roberts, Justice O'Connor acknowledged that

Es Riley $v$ National Federation of the Blind, 487 US 781, 796-97 (1988) (noting that free speech is "a term necessarily comprising the decision of both what to say and what not to say"); Pacific Gas, 475 US at 16; Harper \& Row Publishers, Inc. $v$ Nation Enterprises, 471 US 539, 559 (1985), quoting Estate of Hemingway $v$ Random House, Inc., 23 NY2d 341, 296 NYS2d 771, 778 (1968) ("There is necessarily ... [a] freedom not to speak publicly, one which serves the same ultimate end as freedom of speech in its affirmative aspect."); Wooley $v$ Maynard, 430 US 705, 714 (1977) ("[T]he right of freedom of thought protected by the First Amendment... includes both the right to speak freely and the right to refrain from speaking at all.").

${ }_{64}$ Wooley, 430 US at 714, quoting West Virginia Board of Education $v$ Barnette, 319 US 624, 637 (1943). See also Turner Broadcasting System, Inc. v FCC, 114 S Ct 2445, 2458 (1994) ("At the heart of the First Amendment lies the principle that each person should decide for him or herself the ideas and beliefs deserving of expression.").

6 Roberts, 468 US at 623. See also Wooley, 430 US at 717 ("[T]he state's interest [in] disseminat[ing] an ideology . . . cannot outweigh an individual's First Amendment right to avoid becoming a courier for such message."); Barnette, 319 US at 633-34 ("To sustain the compulsory flag salute [the Court is] required to say that a Bill of Rights which guards the individual's right to speak his own mind, left it open to public authorities to compel him to utter what is not in his mind."); Thomas S. $v$ Flaherty, 699 F Supp 1178, 1203 (W D NC 1988), aff'd, 902 F2d 250 (4th Cir 1990) (Freedom of association "includes freedom from state coerced association.").

os See Pacific Gas \& Electric Co. $v$ Public Utilities Commission of California, 475 US 1, 9-12 (1986) (holding that a state could not compel company to include in its billing a third party's message with which it disagreed); Miami Herald Publishing Co. v Tornillo, 418 US 241, 256-59 (1974) (forcing newspapers to print candidates' replies to editorials is an impermissible burden on editorial control and judgment); West Virginia Board of Education v Barnette, 319 US 624, 631, 633-34 (1943) (holding that school children with religious objections to flag-saluting ceremony have constitutional right to be free from "compulsion ... to declare a belief"). 
an "association's right to define its membership derives from the recognition that the formation of an expressive association is the creation of a voice, and the selection of members is the definition of that voice." ${ }^{\prime} 7$ In litigation, mandatory participation constitutes tangible, measurable, compelled support of the suit's goals and ideas-that is, of its "voice."

To illustrate the assertion that membership alone constitutes support of a class action's goals and ideas, consider that the Supreme Court has understood a cause of action as a property interest. $^{68}$ Since a cause of action represents a property right, then, membership in a class action constitutes a contribution in support of the suit. Use of an absent class member's claim by the class representative is akin to a "taking"-or forced contribution-of the absent class member's property interest.

This point is most clear in a large class action involving only small individual claims. Without aggregation of claims, the interests at stake for the named plaintiffs may be insufficient (from an individual, cost-benefit standpoint) to justify the expense of litigation. However, once those plaintiffs organize a numerous class, the aggregation of interests increases the stakes to a level sufficient to attract, and justify the expense of, legal representation. Such representation is only possible because of the large number of claimants. Certifying the suit as a mandatory class action empowers class members by compelling the aggregation of interests. ${ }^{69}$ Without the "contribution" of the unnamed class members' property interests-that is, their claims-to the litigation, representation might not prove cost effective or even possible. ${ }^{70}$ Mandatory class membership thus increases the resources

${ }^{67} 468$ US at 633 (O'Connor concurring).

क Indeed, the Shutts Court specifically recognized an absent class member's claim for damages as a property interest. 472 US at 807 (recognizing an absent class member's damages claim as "a constitutionally recognized property interest possessed by each of the plaintiffs" in the class). See also Tulsa Professional Collection Services, Inc. v Pope, 485 US 478, 485 (1988) ("Appellant's claim ... is properly considered a [constitutionally] protected property interest."); Logan v Zimmerman Brush Co., 455 US 422, 428-29 (1982) (stating that a cause of action is a protected property interest).

* Weber, 21 U Mich J Legal Ref at 350-51 (cited in note 19) (asserting that the 1966 amendments to Rule 23 , which created subdivision (b)(2), served to empower legal action on behalf of racial minorities and the poor); Herbert B. Newberg, et al, 1 Newberg on Class Actions $\$ 5.02$ at 423-24 (McGraw-Hill 2d ed 1985).

${ }_{70}$ Richard A. Posner, Economic Analysis of Law \$ 21.9 at 569 (Little, Brown 4th ed 1992) ("If [individually insubstantial] claims are aggregated in a class action, the stakes in the action will be large enough to defray the costs of suit."). Note that payment of counsel fees does not remove litigation from First Amendment protection. Primus, 436 US 412,429 (1978) ("[A]ward of counsel fees does not take this case outside of the protection 
available to finance litigation and consequently strengthens the "voice" of the class suit.

This situation is analogous to the one in which an organization with mandatory membership requires contributions from its members. ${ }^{71}$ In Abood $v$ Detroit Board of Education, a group of teachers sought relief from an "agency shop" provision of a collective bargaining agreement that required them to pay dues, even if they were not union members. ${ }^{72}$ State law authorizing union representation of local government employees permitted an arrangement requiring all employees, even if not union members, to be represented by a union, and to pay union dues as a condition of employment. ${ }^{73}$ The Court held that the First Amendment prohibited the unions from conditioning employment on mandatory dues, any portion of which would be used to support political or ideological causes-either through direct expression or support of political candidates-with which employees disagreed. ${ }^{74}$ The Court held that mandatory dues were permissible, but only if they were used to finance activities related to collective bargaining. ${ }^{75}$ When the teachers' union departed from that goal, it ceased to act in furtherance of the "cause" that brought about its formation. Thus, while the union was permitted some leeway in furthering the common goal of collective bargaining, individuals' First Amendment interests in expression and association prevented compelled financial support of the union's political or ideological activities. ${ }^{76}$

In Abood, the Court stated that its previous decisions "establish [ed] with unmistakable clarity that the freedom of an individual to associate for the purpose of advancing beliefs and ideas is protected by the First and Fourteenth Amendments." ${ }^{.77}$ Indeed,

of Button.").

1 See Galda $v$ Rutgers, 772 F2d 1060, 1066 (3d Cir 1985) (holding that state university's funding mechanism that required mandatory student contributions to an independent, outside, nonprofit corporation that engaged in research, lobbying, and litigation for "social change" violated First Amendment rights of dissenting students); Galda $v$ Bloustein, 686 F2d 159, 163-64 (3d Cir 1982), judgment vacated by Galda v Rutgers, 772 F2d 1060 (holding that without compelling state interest, refund mechanism alone failed to remedy infringement of First Amendment rights).

72431 US 209, 212-13 (1977).

73 Id.

${ }^{74}$ Id at 233-36.

75 Specifically, the Court held that the union could not, consistent with the First Amendment, require objecting employees to fund political or ideological goals "not germane to its duties as collective-bargaining representative." Id at 235-36.

${ }^{76}$ Id at $222-23$.

77 Id at 233. 
teachers challenging agency-shop arrangements like those in Abood might oppose not just the union's ideological views and political activities, but also the very idea of public-sector unions. Thus, as Justice Powell recognized in his concurring opinion, mandatory affiliation with the union through the medium of a compelled contribution infringes First Amendment rights "to the same degree as compelling them to contribute to a political party." 78

Similarly, in Keller $v$ State Bar, attorneys challenged the constitutionality of an integrated state bar association's use of compulsory dues to finance political and ideological activities with which the attorneys disagreed. ${ }^{79}$ The Court held that the use of dissenters' compulsory dues to finance such activities violated constitutionally protected rights of free speech and association when such expenditures were not "necessarily or reasonably incurred for the purpose of regulating the legal profession or "improving the quality of the legal service." that while it is appropriate that lawyers who benefit from their bar membership pay their share of the profession's collective expenses, a state bar association may not use mandatory dues to fund "activities of an ideological nature," such as promoting nuclear-freeze initiatives or gun-control measures. ${ }^{81}$

In both Abood and Keller, the Supreme Court acknowledged the difficulty associated with drawing lines between "political and ideological" activities unrelated to an organization's primary mission and those activities for which contributions may be constitutionally compelled. ${ }^{82}$ Such admissions, however, do not undermine the Court's conclusion that coerced contributions to political or ideological activities violate First Amendment rights. Indeed, the Keller Court specifically rejected the idea that such line drawing represented an "extraordinary burden," noting that

${ }^{78}$ Id at 257 (Powell concurring). See also New York County Board of Ancient Order of Hibernians v Dinkins, 814 F Supp 358, 363-64 (S D NY 1993), citing Roberts, 468 US 609 ("The right of association contemplates not merely the nature of the association, but the message conveyed or the ideas expressed by way of that association.").

79496 US 1, 4 (1990).

so Id at 14, quoting Lathrop v Donohue, 367 US 820, 843 (1961) (plurality opinion).

${ }^{81}$ Keller, 496 US at 12, 14, 16.

${ }^{82}$ Abood, 431 US at 236 ("There will, of course, be difficult problems in drawing lines between collective-bargaining activities, for which contributions may be compelled, and ideological activities unrelated to collective bargaining, for which such compulsion is prohibited."); Keller, 496 US at 15 ("Precisely where the line falls between [activities related to regulation of the legal profession] . . . and those activities having political or ideological coloration... will not always be easy to discern."). 
unions had operated successfully under Abood for over ten years. $^{83}$

The Court's consideration of mandatory, legislative limits on political campaign contributions in Buckley $v$ Valeo also sheds light on the First Amendment problems associated with mandatory class actions. ${ }^{84}$ Because the act of contributing to a political campaign "enables like-minded persons to pool their resources in furtherance of common political goals," the Court found that contribution limitations involve "fundamental First Amendment interests. ${ }^{855}$ Although the Court ultimately permitted contribution limitations, its analysis supports the Abood-Keller ban on forced contributions because the essence of the right to associate was implicated in the act of contributing itself. ${ }^{86}$ Thus, the contribution restriction was permissible because it did not prevent a contributor from affiliating with a candidate; instead, it only limited the amount a contributor could spend to further that affiliation. ${ }^{87}$ Since the "symbolic expression of support" was the contribution itself, regardless of its size, limitations had no "dramatic, adverse effect on ... political associations." of the Buckley Court, then, the inescapable conclusion was that a contribution of any size served to affiliate contributor with recipient. Thus, it follows logically that because such affiliation cannot be precluded consistent with the First Amendment, neither can it be compelled.

The idea that forced contributions constitute coerced expressive association is not new. Thomas Jefferson agreed that "to compel a man to furnish contributions of money for the propagation of opinions which he disbelieves, is sinful and tyrannical." And, after Abood and Keller, it is clear that a mandatory contribution to an entity whose goals are political or ideological is coercive and prohibited by the First Amendment. ${ }^{90}$ Indeed, after

'3eller, 496 US at 16-17.

424 US 1,23 (1976).

$\therefore$ Id at $22-23$.

is Id at 22 ("The [Federal Election Campaign] Act's contribution and expenditure limitations also impinge on protected associational freedoms. Making a contribution, like joining a political party, serves to affiliate a person with a candidate.").

\$7 Id at 20-22.

$\approx$ Id.

sy Abood, 431 US at 235 n 31, quoting Irving Brant, James Madison: The Nationalist 354 (Bobbs-Merrill 1948). See also Barnette, 319 US at 642 ("If there is any fixed star in our constitutional constellation, it is that no official, high or petty, can prescribe what shall be orthodox in politics, nationalism, religion, or other matters of opinion or force citizens to confess by word or act their faith therein.").

s: Abood, 431 US at 234 ("[C]ontributing to an organization for the purpose of spread- 
Abood, it appears that any compelled payment, regardless of whether membership is compelled, infringes the right of expressive nonassociation. ${ }^{91}$

Like the forced contributions in Abood and Keller, mandatory participation in a class action constitutes compelled support of the suit's goals and ideas through coerced payment of a type of "contribution." Indeed, one of the goals of class actions is to aggregate individual interests to empower class members. ${ }^{92}$ This empowerment explosion appears in the fact that a very high proportion of the class actions filed are plaintiffs' civil rights actions. $^{93}$

Quite simply, the group empowerment associated with the class action device has come at the expense of constitutionally protected individual liberty. Mandatory class participation, and its inherent "contribution," unavoidably implicate constitutionally protected expression, because compelled membership serves to associate the class member with the ideas and goals of the class action. Regardless of a class member's ability to otherwise disassociate herself from the purposes of the litigation, compelled membership implicates and infringes the expressive and associational rights protected by the First Amendment. ${ }^{94}$

ing a political message is protected by the First Amendment."). See also Elrod $v$ Burns, 427 US 347, 355 (1976) (holding that an assessment on a patronage employee's salary is "tantamount to coerced belief").

${ }_{91}$ Compare Abood, 431 US at $217 \mathrm{n} 10$ (finding it not relevant that the agency-shop agreement, unlike the union-shop agreement, required only the payment of dues and not formal membership), with Lathrop, 367 US at 843-47 (finding infringement of associational rights slight because membership in integrated bar association was limited to compulsory payment of dues). Note also that the size of a coerced contribution is irrelevant to its constitutionality. See Chicago Teachers Union v Hudson, 475 US 292, 305-06 (1986) (noting that the "amount at stake" does not affect concerns regarding compelled support of political or ideological views).

92 See notes 69, 155 and accompanying text.

93 In 1990, civil rights actions constituted the largest category of federal class cases filed, with 18.3 percent of the total. In 1991, they remained the second largest category with 17 percent. See Administrative Office of the United States Courts, 1991 Annual Rep of the Director 367 (1991).

94 See Pacific Gas, 475 US at 15-16 (holding that the choice between being forced either to appear to agree with another's views or to affirmatively disavow those views is the "kind of forced response [that] is antithetical to the free discussion that the First Amendment seeks to foster"). 


\section{Constitutional InTEREsts Implicated By A FirST AMENDMENT RIGHT TO OPT OUT}

Section II outlined the expressive and associational interests at stake when membership in a class action is mandatory. It also demonstrated the applicability of the First Amendment to mandatory class actions and the constitutional liberties they implicate. ${ }^{95}$

Regulations that impinge on First Amendment rights always receive "exacting judicial review." ${ }^{\text {"96 }}$ Like the right to speak itself, however, the right to opt out expounded in Section II cannot be absolute. ${ }^{97}$ Speech may be regulated where its unfettered use proves incompatible with fair litigation. ${ }^{98}$ Thus, before accepting a First Amendment right to opt out of class actions, one must determine its limits.

Having established that mandatory class actions implicate First Amendment rights, one must locate them within the jurisprudence defining those rights. The key question is by what standard should the constitutionality of mandatory class actions be judged. This question hinges on three First Amendment interests. First, one must ask whether compelled membership affects the content of expression. The Supreme Court is far more deferential to "content-neutral" regulations of expression than to regulations that seek to restrict expression because of the message it conveys. ${ }^{99}$ Second, one must consider the weight of the state's interest in regulating expression. The Court is more deferential to state interests it considers "compelling" than to those that are merely "substantial." 100 Third, one must take into account the nature of the expression the state seeks to regulate. Expression or association that is political in nature receives the highest level of First Amendment protection, whereas the Court is more defer-

95 See Clark v Community for Creative Non-Violence, 468 US 288, 293 n 5 (1984) ("Although it is common to place the burden upon the Government to justify impingements on First Amendment interests, it is the obligation of the person desiring to engage in assertedly expressive conduct to demonstrate that the First Amendment even applies.").

96 Citizens Against Rent Control v City of Berkeley, 454 US 290, 294 (1981).

${ }^{97}$ Roberts, 468 US at 623 ("The right to associate for expressive purposes is not [ ] absolute."); American Communications Association v Douds, 339 US 382, 394, 399 (1950) (same); Konigsberg $v$ State Bar, 366 US 36, 49-51 (1961) (same).

3 Chicago Council of Lawyers v Bauer, 522 F2d 242, 248 (7th Cir 1975), quoting Estes $v$ Texas, 381 US 532, 540 (1965) (noting the court's responsibility to ensure a fair trial, which is "the most fundamental of all freedoms").

\&9 Geoffrey R. Stone, Content-Neutral Restrictions, 54 U Chi L Rev 46, 48 (1987).

See Roberts, 468 US at 623; Schneider v State, 308 US 147, 161 (1939). 
ential to state regulation of "low-value" expression, such as commercial speech. ${ }^{101}$

\section{A. Mandatory Class Actions: Not Content Neutral As Applied}

At first glance, mandatory class actions appear to be content neutral. ${ }^{102}$ Classes are certified according to the dictates of Rule 23 regardless of the subject of the suit. But, as applied, mandatory membership in a class action is not content neutral. ${ }^{103}$ Thus, absent narrowly drawn regulations serving compelling state interests, ${ }^{104}$ infringements of First Amendment rights must fall.

The essence of the First Amendment right at issue in the mandatory class action context is freedom from compelled expression and association. In Riley $v$ National Federation of the Blind, Inc., the Court considered a state law requiring professional fundraisers to disclose to potential donors, before a solicitation, the percentage of contributions actually distributed to charity (as compared with the percentage used for other expenses, such as administrative costs and salaries) in the previous year. ${ }^{105}$ The Court recognized such disclosures as compelled expression and held that "[m]andating speech that a speaker would not otherwise make necessarily alters the content of the speech."106 The Court held, therefore, that the state regulation was content based, and, as such, subject to "exacting First Amendment scrutiny."107

101 See, for example, Central Hudson Gas \& Electric Corp v Public Service Commission of New York, 447 US 557, 562-66 (1980) ("The Constitution [ ] accords a lesser protection to commercial speech than to other constitutionally guaranteed expression."); Mills v Alabama, 384 US 214, 218 (1966) ("[T]here is practically universal agreement that a major purpose of the First Amendment was to protect the free discussion of governmental affairs."); Buckley, 424 US at 14-15 (holding that freedom of expression "has its fullest and most urgent application precisely to the conduct of campaigns for political office").

${ }_{102}$ See text accompanying note 99.

103 Where a limitation on speech is not "facially invalid" (that is, unconstitutional on its face regardless of its effects in a particular situation), courts analyze the actual effects of the limitation "as applied." See, for example, Poulos $v$ New Hampshire, 345 US 395, 403-08 (1953) (noting that ordinances regulating use of public parks do not violate First Amendment unless they grant officials complete discretion to refuse use to a group or individual).

${ }^{104}$ See, for example, R.A.V. $v$ City of St. Paul, 505 US 377, 382 (1992) ("Content-based regulations are presumptively invalid."); Perry Education Association $v$ Perry Local Educators' Association, 460 US 37, 45 (1983) (The strict scrutiny standard applied to content based regulations is that the restriction must be "necessary to serve a compelling state interest and ... narrowly drawn to achieve that end.").

105487 US 781, 784 (1988).

${ }^{106}$ Id at 795 . See also note 94 .

107 Riley, 487 US at 795, 798. See also McIntyre v Ohio Elections Commission, $115 \mathrm{~S}$ Ct 1511, 1518 (1995) (holding that a statute prohibiting the distribution of campaign 
Like the right to be free from compelled expression, the right to be free from compelled association, while not absolute, is entitled to a high degree of protection. In Roberts, the all-male Jaycees challenged a state statute forbidding discrimination on the basis of sex. ${ }^{108}$ The Court found that the right implicated by Jaycee membership fell under the second category of freedom of association, the right of expressive association. ${ }^{109}$ As such, the Court held that only "compelling state interests" could justify infringements that could not be achieved by "means significantly less restrictive of associational freedoms."110

It is important to note that some forms of communication are only possible because of financial contributions. ${ }^{111} \mathrm{~A}$ forced contribution to a lawsuit can enhance the quantity and quality of expression by increasing the resources available for litigation. ${ }^{112}$ This permits lawyers to hire more personnel, to consider more issues, and to research those issues in greater depth. ${ }^{113}$ Since restricting "the amount of money a person or a group can spend on political communication" is constitutionally impermissible, ${ }^{114}$ compelling membership in a class action must also impair First Amendment rights. This is because mandatory class actions require de facto contributions from absent members for expression those members may not support, and as the Court has explained, such compelled speech necessarily changes the meaning (content) of the speech. For these reasons, the compelled expression and

literature that does not contain the name and address of the person or organization distributing the literature, "even though [it] applies evenhandedly to advocates of differing viewpoints, [ ] is a direct regulation of the content of speech") (emphasis added). Note that compelled statements of fact burden expression to the same extent as compelled statements of opinion. Riley, 487 US at 797-98.

109468 US at 615 .

${ }_{109}$ Id at 617-23. See also text accompanying notes 49-52.

${ }^{110}$ Id at 623. See also Abood, 431 US at 225 ("[I]mportant government interests ... presumptively support the impingement upon associational freedom created by the [statute] at issue.").

${ }^{111}$ See Buckley, 424 US at 16. See also text accompanying notes 84-88.

112 See Buckley, 424 US at 19, 65-66 (stating that freedom of association is "diluted if it does not include the right to pool money through contributions, for funds are often essential if 'advocacy' is to be truly or optimally 'effective").

113 See id at 19.

114 Id. See also Citizens Against Rent Control $v$ City of Berkeley, 454 US 290, 299 (1981) (noting that the significant restraint on freedom of expression was "virtually inseparable" from the impermissible restraint on freedom of association); William $P$. Marshall, Village of Schaumburg v. Citizens for a Better Environment and Religious Solicitation: Freedom of Speech and Freedom of Religion Converge, 13 Loyola LA L Rev 953, 973 (1980) ("The grant or denial of a contribution is itself an expression of advocacy."). 
association inherent in mandatory class actions alter the content of the litigation and are thus justified only where compelling state interests are served by narrowly drawn regulations. ${ }^{115}$

Proponents of mandatory class actions cannot argue that limitations on the expressive and associational rights of potential dissenters are necessary to facilitate the expression and petition rights of class members. The Supreme Court has unequivocally stated that "the concept that government may restrict the speech of some elements of our society in order to enhance the relative voice of others is wholly foreign to the First Amendment."116 Regulations enhancing the voice of group litigants at the expense of individuals who would, but are not allowed to, opt out must therefore survive strict scrutiny analysis, if they are to survive at all. ${ }^{117}$

\section{B. State Interests: Not Clearly in Genuine Jeopardy}

It seems clear that the state has a compelling interest in providing a forum for fair and efficient litigation. However, the state's interest in permitting mandatory class actions in the wide array of circumstances permitted by Rules 23(b)(1) and (b)(2) is not similarly compelling.

The Supreme Court has recognized that class certification does advance the efficiency of litigation and that this "is a principal purpose of the procedure."118 Equally important are considerations that parties not be disadvantaged by piecemeal litigation (plaintiffs by limited funds and defendants by inconsistent verdicts) and that litigants with limited resources have access to the courts. ${ }^{119}$ However, "the interest of the judiciary in the proper administration of justice does not authorize any blanket exception to the first amendment." ${ }^{20}$ In Turner Broadcasting System,

115 Riley, 487 US at $795,798$.

${ }^{116}$ Buckley, 424 US at 48-49.

11 Id. See also Pacific Gas \& Electric Co. $v$ Public Utilities Commission, 475 US 1, 20 (1986) ("Our cases establish that the State cannot advance some points of view by burdening the expression of others."). But compare Turner Broadcasting System, Inc. v FCC, 114 S Ct 2445, 2467 (1994) (construing Buckley's holding to mean that laws favoring some speakers at the expense of others "demand strict scrutiny when they reflect the Government's preference for the substance of what the favored speakers have to say").

118 General Telephone Co. $v$ Falcon, 457 US 147, 159 (1982), quoting American Pipe \& Construction Co. $v$ Utah, 414 US 538, 553 (1974). See also Califano $v$ Yamasaki, 442 US 682, 701 (1979) (noting that the purpose of Rule 23 is to promote judicial economy by allowing for litigation of common questions of law and fact at one time).

119 United States Parole Commission v Geraghty, 445 US 388, $402-03$ (1980).

${ }^{20}$ Bernard $v$ Gulf Oil Co., 619 F2d 459, 474 (5th Cir 1980), quoting Rogers v United 
Inc. $v F C C$, a recent case challenging a federal statute requiring cable operators to carry local broadcast stations, the Supreme Court held that the state bears the burden of proof when its regulations affect First Amendment rights. ${ }^{121}$ Writing for a plurality of the Court, Justice Kennedy stated:

When the Government defends a regulation on speech as a means to redress past harms or prevent anticipated harms, it must do more than simply "posit the existence of the disease sought to be cured." It must demonstrate that the recited harms are real, not merely conjectural, and that the regulation will in fact alleviate these harms in a direct and material way. ${ }^{122}$

The Turner Court first inquired whether the state had adequately shown the economic health of local broadcasting to be in "genuine jeopardy." 23 Citing the absence of evidence supporting this threat, the Court rejected the state's assertion and remanded the case. ${ }^{124}$ Significantly, the Court held that the state bears the burden of proof when it seeks to regulate behavior protected by the First Amendment. ${ }^{125}$

Applying this "threshold" test to the right to opt out of class actions, the initial inquiry becomes whether the state has adequately shown that fairness and efficiency of litigation stand in "genuine jeopardy" without the protections provided by mandatory class certification provisions. ${ }^{126}$ Moreover, the Court may answer this question independently; the deference given to legislative findings does not foreclose the Supreme Court from making

States Steel Corp, 508 F2d 152, 163 (3d Cir 1975) (emphasis added). For cases holding that courts cannot exercise their contempt power in a way that abridges First Amendment rights absent a showing of an actual interference with the administration of laws, see Wood $v$ Georgia, 370 US 375 (1962); Craig v Harney, 331 US 367 (1947); Pennekamp v Florida, 328 US 331 (1946); Bridges v California, 314 US 252 (1941).

21114 S Ct 2445, 2470 (1994) (plurality opinion).

122 Id (citations omitted). See also Edenfield $v$ Fane, 113 S Ct 1792, 1798-99 (1993) (stating courts must decide "whether the State's interests in proscribing [speech] are substantial; whether the challenged regulation advances these interests in a direct and material way; and whether the extent of the restriction on protected speech is in reasonable proportion to the interests served"); City of Los Angeles $v$ Preferred Communications, Inc., 476 US 488, 496 (1986), quoting City of Los Angeles $v$ Taxpayers for Vincent, 466 US 789, $803 \mathrm{n} 22$ (1984) ("This Court 'may not simply assume that the ordinance will always advance the asserted state interests sufficiently to justify its abridgment of expressive activity.").

123 Turner, 114 S Ct at 2470, 2472 (plurality opinion).

124 Id at 2472.

125 See note 122.

${ }^{125}$ See Turner, $114 \mathrm{~S}$ Ct at 2470 (plurality opinion). 
an "independent judgment of the facts bearing on an issue of constitutional law."127 To withstand scrutiny, the Court must conclude that Congress has drawn "reasonable inferences based on substantial evidence." 128

The arguments favoring mandatory class actions are not conclusive on their face and indeed are open to debate. ${ }^{129}$ To begin, the broad discretion vested in courts by Rule $23^{130}$ undermines the goal of judicial consistency. ${ }^{131}$ For example, courts have wide discretion in the initial certification of class actions. Many class suits can be certified as either mandatory or permissive because most classes meeting the stricter qualification standard for mandatory status also meet the lower standard for permissive status. ${ }^{132}$ In practice, this discretion has tended to follow a default rule: courts usually err in the direction of mandatory class certification. ${ }^{133}$ Indeed, the Manual for Complex Litigation notes that if the conditions of $(b)(1)$ or $(b)(2)$ are met as well as those of (b)(3), the court is not required to give notice or to permit members to opt out. ${ }^{134}$ This discretion also permits courts to use varying standards for certification and subcertification. ${ }^{135}$ Uneven standards and an incentive for fo-

127 Id at 2471, quoting Sable Communications, Inc. v FCC, 492 US 115, 129 (1989).

128 Turner, $114 \mathrm{~S}$ Ct at 2471 (plurality opinion).

${ }^{129}$ See, for example, Edward F. Sherman, Aggregate Disposition of Related Cases: The Policy Issues, 10 Rev Litig 231, 237-54 (1991); Richard A. Epstein, The Consolidation of Complex Litigation: A Critical Evaluation of the ALI Proposal, $10 \mathrm{~J}$ L \& Commerce 1, 1516 (1990); Edward J. Brunet, A Study in the Allocation of Scarce Judicial Resources: The Efficiency of Federal Intervention Criteria, $12 \mathrm{Ga}$ L Rev 701, 710-20 (1978).

${ }^{130}$ See First Federal of Michigan v Barrow, 878 F2d 912, 919 (6th Cir 1989) (noting wide discretion of trial courts in controversies of certification).

${ }_{131}$ When Rule 23 was redrafted, the mandatory class actions that it recognized were intended to address primarily the danger of separate actions creating inconsistent results for parties. FRCP 23, Advisory Committee Notes to 1966 Amendment.

${ }^{132}$ This is true because, after Rule 23(a), subsection (b)(3) requires only that "common questions predominate" and that the class action device be "superior" to other available methods of litigation. Any class meeting the higher threshold of subsections $(b)(1)$ or $(b)(2)$ would inherently satisfy subsection (b)(3)'s requirements. FRCP 23.

${ }^{133}$ See Newberg, et al, 1 Newberg on Class Actions $\$ 4.20$ at 310-12 (cited in note 69); Wright, Miller, and Kane, 7A Federal Practice and Procedure $\S 1775$ at 470 (cited in note 23) ("If the Rule 23(a) prerequisites have been met and injunctive or declaratory relief has been requested, the action usually should be allowed to proceed under subdivision (b)(2). Those aspects of the case not falling within Rule 23(b)(2) should be treated as incidental."). See, for example, Barrow, 878 F2d at 919 (holding that when the choice exists between (b)(1) and (b)(3) certification, generally it is proper to proceed under (b)(1) exclusively in order to avoid inconsistent adjudication or a compromise of class interests); Cook $v$ Rockwell International Corp, 151 FRD 378, 388 (D Colo 1993) (holding that "when class certification is validly sought in the alternative under Rule $23(\mathrm{~b})(2)$ and (b)(3), a mandatory (b)(2) class is preferred").

${ }^{134}$ Pointer, et al, Manual for Complex Litigation $\S 30.14$ at 218-19 (cited in note 14).

${ }^{135}$ See text accompanying notes 24-25, 37. Subcertification occurs when a distinct sub- 
rum shopping result. ${ }^{136}$ Nor do mandatory class actions necessarily serve judicial efficiency. Parties engage in extensive collateral litigation over whether the class was properly certified, and absent class members frequently appeal final orders and settlements. ${ }^{137}$ Class actions also lead to collateral litigation regarding the adequacy of class representation. ${ }^{138}$ Thus, logic suggests that the very cases in which absent class members are prevented from exercising their opt-out rights are those in which they can be expected to mount a collateral attack against the adequacy of their representation. Since determining whether representation was adequate depends in large part on the strength of the absent class members' claims, the courts that review collateral challenges must review the merits of the absent class members' individual claims. Thus, mandatory class actions may exacerbate the very problem they were designed to avoid.

Settlements also provide a problem for class actions. Rule 23(e) requires that class members receive notice in the event of a settlement proposal, but it does not give objecting members a right to opt out; thus, more collateral litigation may be initiated by absent class members who reject the proposed settlement. ${ }^{139}$ The final goal of class actions is to provide small claimants access to the courts, and mandatory class actions do further this goal. However, permissive class actions likewise serve this goal, and have the advantage of doing so without the accompanying potential for conflicts in interests among class members and between lawyers and class members. ${ }^{140}$

class in a proposed class is certified by a court. Pointer, et al, Manual for Complex Litigation $\S \S 30.15-30.17$ at $219-23$ (cited in note 14).

${ }^{135^{\circ}}$ See Miller and Crump, 96 Yale L J at 52-54, 57-59 (cited in note 3).

137 See, for example, Shults v Champion International Corp., 35 F3d 1056, 1059-60 (6th Cir 1994) (noting circuit split regarding whether nonnamed class members have standing to appeal final orders in class action suits). See also text accompanying notes 173-81.

${ }^{139}$ See Green v Santa Fe Industries, 82 FRD 688, 689 (S D NY 1979).

133 See Brown v Ticor Title Insurance Co., 982 F2d 386, 390 (9th Cir 1992), cert granted, 114 S Ct 56 (1993), cert dismissed as improvidently granted, 114 S Ct 1359 (1994); In re Real Estate Title \& Settlement Serv. Antitrust Litig., 869 F2d 760, 764-65 (3d Cir 1989). There currently are three different judicial positions on the ability of absent class members to appeal class action settlements. See generally, Timothy A. Duffy, Comment, The Appealability of Class Action Settlements By Unnamed Parties, $60 \mathrm{U}$ Chi L Rev 933, 934-40 (1993).

${ }^{140}$ See Pettway v American Cast Iron Pipe Co., 576 F2d 1157, 1169 (5th Cir 1978) ("The interests of lawyer and class may diverge, as may the interest of different members of the class, and certain interests may be wrongfully compromised, betrayed, or 'sold out' without drawing the attention of the court."); Plummer v Chemical Bank, 668 F2d 654, 658 (2d Cir 1982) ("Because of the limited control exercisable by class members, class 
In short, the First Amendment places on the proponents of mandatory class actions the burden of proving that these suits serve important public interests. The assertion that mandatory class actions serve the values recognized by their proponents remains debatable. Moreover, class actions offer no exception to the rule that efficiency is not a determinative concern in the area of constitutional rights. ${ }^{141}$ If the inability of a class member to opt out of a mandatory class action implicates a significant First Amendment right, that right trumps any state interest in judicial efficiency. ${ }^{142}$

\section{Individual Interests: Recognizing Two Categories of First Amendment Opt-Out Rights}

The state's interest in fair and efficient adjudication of litigation does not vary with the issues at bar. If members of the class are more numerous, that interest may be quantitatively greater, but it remains the same in kind. By contrast, a litigant's interests vary with the nature of the suit. Where the goals sought by the litigation are fundamentally "political" or "constitutional," the government may be unable to justify limitations on the expression and association inherent in an individual's decision to opt out. However, where the goals sought by the litigation are "commercial" or "economic," the government can justify those limitations more easily.

The Button Court arguably limited its First Amendment protection of litigation to the expression of political rights. ${ }^{143}$ However, the Patterson Court previously had appeared to dismiss

settlements are susceptible to abuse.").

${ }^{141}$ See INS $v$ Chadha, 462 US 919, 944 (1983) ("[T] dure is efficient, convenient, and useful in facilitating functions of government, standing alone, will not save it if it is contrary to the Constitution. Convenience and efficiency are not the primary objectives... and our inquiry is sharpened rather than blunted" by the increasing use of an arguably efficient procedure.); Keller, 496 US at 16-17, quoting Keller $v$ State Bar, 47 Cal 3d 1152, 255 Cal Rptr 542, 568 (1989) (Kaufman concurring in part and dissenting in part) (noting that the fact that procedures are likely to "result in some additional administrative burden ... [and are] inconvenient... is hardly sufficient to justify contravention of the constitutional mandate").

${ }_{142}$ Riley, 487 US at 795 ("[T]he First Amendment does not permit the State to sacrifice speech for efficiency."); Bridges, 314 US at 263, citing Schneider v State, 308 US 147, 161 (1939) (holding that the expression of "legislative preferences or beliefs" cannot transform minor matters of public inconvenience or annoyance into substantive evils of suffcient weight to warrant the curtailment of free expression).

143 Button, 371 US at 443. 
the idea that such protection depends on the nature of the goals sought to be advanced:

Of course, it is immaterial whether the beliefs sought to be advanced by association pertain to political, economic, religious or cultural matters, and state action which may have the effect of curtailing the freedom to associate is subject to the closest scrutiny. ${ }^{144}$

Justice Harlan's dissent in Button picked up on this discord and implied that if the First Amendment protected litigation as a form of expression, that protection extended to all sorts of litigation, regardless of its goals. ${ }^{145}$ More recently, the Court found implicit in the right to engage in activities protected by the First Amendment a corresponding right to associate with others in pursuit of a wide variety of political, social, economic, educational, religious, and cultural ends. ${ }^{146}$ However, a freedom to associate (with a corresponding right not to associate), unlimited by the ends sought, would imply a virtually absolute right to opt out. First Amendment jurisprudence suggests a more modest solution.

As the First Amendment applies to mandatory class actions, one can perceive a qualitative distinction between the expression and association implicated in different types of litigation. The Abood-Keller analysis is helpful here. Abood and Keller struck a balance between the individual's First Amendment interests and the collective interests served by mandatory membership in, and contribution to, an organization. ${ }^{147}$ These Courts recognized that the individual's right to be free from coerced expression and association is greatest when in pursuit of those ideas essential to First Amendment rights, those implicating "individual freedom of mind." Fis For this reason, both cases recognized an absolute right to be free from coerced expression or coerced association regarding political ends. ${ }^{149}$ The individual's right became more

144 Patterson, 357 US at 460-61. See also Thomas v Collins, 323 US 516, 531 (1945) (" $[T]$ he rights of free speech and a free press are not confined to any field of human interest."). Compare Button, 371 US at 441-43 (noting that NAACP pursues litigation out of political motives and not for personal gain).

145 Button, 371 US at $452-55$ (Harlan dissenting) ("We have passed the point where litigation is regarded as an evil that must be avoided ... . Litigation is often the desirable and orderly way of resolving disputes of broad public significance, and of obtaining vindication of fundamental rights.").

${ }^{146}$ Roberts, 468 US at 622.

147 See Abood, 431 US at 235-36; Keller, 496 US at 12-14.

${ }_{149}$ West Virginia Board of Education v Barnette, 319 US 624, 636-37 (1943). See also note 64 and accompanying text.

${ }^{149}$ See Abood, 431 US at 234-36; Keller, 496 US at 13-14. This freedom has also been 
easily compromised when the goals served remained consistent with the group's collective interest.

The right of association may be best understood as being bifurcated two separate times. As noted, Patterson divided the associative right into individual and collective components. ${ }^{150}$ Button then divided the collective component into two separate rights of collective association. The first right was that of "political association" in pursuit of activities independently protected by the First Amendment. ${ }^{151}$ The second right was that of "commercial association," in pursuit of goals unrelated to other fundamental constitutional rights. ${ }^{152}$

This separation of the right of collective association for litigation into "political" and "economic" categories is consistent with existing free speech jurisprudence. For example, the Court has held that commercial speech will receive less constitutional protection than noncommercial, or political, speech. In Metromedia, Inc. $v$ City of San Diego, the Court held that a city "does not have the same range of choice in the area of non-commercial speech to evaluate the strength of, or distinguish between, various communicative interests" as it does with commercial speech. ${ }^{153}$ If there exist two types of rights of collective association based on the goals pursued by a group, it is clear that some types of association deserve greater protection than others. In her concurrence in Roberts, Justice O'Connor stated:

[A]n association engaged exclusively in protected expression enjoys First Amendment protection of both the content of its message and the choice of its members. ... [But] there is

confirmed in cases where the compulsion is a result of private contract between employer and union rather than by statute. See Communications Workers of America $v$ Beck, 487 US 735, 745 (1988) (obligation is to support union activities "germane to collective bargaining"); Abood, 431 US at 232, quoting Harry H. Wellington and Ralph $\mathrm{K}$. Winter, Jr., The Unions and the Cities 95-96 (Brookings 1971) (" $[\mathrm{D}]$ ifferences between public- and private-sector collective bargaining simply do not translate into differences in First Amendment rights. ... No special dimension results from the fact that a union represents public rather than private employees." $)$.

150 See text accompanying notes 49-52.

151 Button, 371 US at 440 ("[T] constitutional rights through litigation, as a matter of law, cannot be deemed malicious.").

152 Id at 443 ("Resort to the courts to seek vindication of constitutional rights is a different matter from the oppressive, malicious, or avaricious use of the legal process for purely private gain.").

${ }^{153} 453$ US 490, 514 (1981). See also Bolger $v$ Youngs Drug Products Corp, 463 US 60, 64-65 (1983) (holding that "the Constitution accords less protection to commercial speech than to other constitutionally safeguarded forms of expression"). 
only minimal constitutional protection of the freedom of commercial association. ${ }^{154}$

Thus, a First Amendment-based right to opt out of mandatory class actions would seem particularly strong when the class action seeks to enforce noncommercial or political rights. ${ }^{155}$

The First Amendment approach to mandatory class actions adopts reasoning parallel to that of Button and the Abood-Keller cases. Specifically, it distinguishes between litigation in pursuit of political ends and litigation in pursuit of commercial ends. As noted, this could prove a difficult line to draw. ${ }^{156}$ Unlike Abood and Keller, litigation has no preestablished baseline by which to judge whether an activity is permissible or impermissible. It is relatively easy to determine when a union is acting outside the bounds of collective bargaining or when a bar association is pursuing goals that do not further regulation of the legal profession. ${ }^{157}$ By contrast, it may be more difficult to decide if a Title VII suit asserts civil rights of equal protection or seeks primarily financial gain. Nonetheless, courts must draw this line if they are to protect the First Amendment rights implicated by mandatory class actions.

\section{ReConciling the Constitutional Dilemma: MoRe NARROWLY DRAWN ALTERNATIVES}

For class actions seeking political goals, limitations on the right to opt out must pass strict scrutiny, that is, they must be narrowly drawn restrictions serving compelling state inter-

14 Roberts, 468 US at 633-34 (O'Connor concurring). See also United States Jaycees $v$ McClure, 709 F2d 1560, 1568 (8th Cir 1983), rev'd on other grounds by Roberts, 468 US 609 ("It may be, for example, that association for ends specifically mentioned in the First Amendment will prevail against all state interests not regarded as 'compelling,' while other kinds of association may be required to yield to less imperative demands of public policy.").

15 Paradoxically, it is precisely these rights that Rule 23(b)(2) was conceived to pursue. The drafters used civil rights actions to illustrate subsection (b)(2)'s use. See FRCP 23(b)(2), Advisory Committee Notes to 1966 Amendment ("Illustrative [of actions under subdivision (b)(2)] are various actions in the civil rights field where a party is charged with discriminating unlawfully against a class."). The notes are careful, though, to state that the subdivision is not limited to civil rights cases. Id.

${ }_{156}$ See text accompanying notes 82-83.

157 Keller, 496 US at 15-16 (barring use of compulsory bar association dues in supporting a gun-control initiative or a nuclear-weapons freeze as obviously political). See also International Association of Machinists v Street, 367 US 740, 777 (1961) (Douglas concurring) (noting that activities "to promote or oppose birth control, to repeal or increase taxes on cosmetics, to promote or oppose the admission of Red China into the United Nations" are among those beyond the mission of a union). 
ests. ${ }^{158}$ This is a demanding standard; the Court has invalidated almost every content-based restriction it has considered under strict scrutiny in the last thirty-five years. For class actions seeking commercial goals, however, limitations on the right to opt out need only satisfy intermediate scrutiny, that is, they must be justified by a showing that the use of a less restrictive alternative would seriously undermine substantial governmental interests. ${ }^{159}$ Like strict scrutiny, intermediate scrutiny also often results in invalidation of the challenged restriction.

This Section analyzes the First Amendment interests under the two categories of the opt-out right outlined in Section III, and determines that the state can achieve its asserted interests in the class action context through regulations more narrow than a prohibition on opting out.

\section{A. The Right to Opt Out of Political Class Actions}

The state interests outlined in Section III.B are not compelling, and therefore they are insufficient to justify the compelled expression and association inherent in mandatory class actions. Even assuming, arguendo, that mandatory class actions do serve compelling state interests, those interests still "cannot be pursued by means that broadly stifle fundamental personal liberties when the end can be more narrowly achieved." "The discussion below uses a concrete example to demonstrate the First Amendment interests at stake in a mandatory class action and shows how the state can regulate more narrowly than the existing prophylactic rule, which denies the right to opt out without exception.

The Court has held that litigation asserting civil liberties constitutes the type of political expression that Button found to be protected by the First Amendment. ${ }^{161}$ In Plummer $v$ Chemi-

158 See Burson v Freeman, 504 US 191, 199 (1992) ("To survive strict scrutiny, [ ] a State must do more than assert a compelling state interest-it must demonstrate that its law is necessary to serve the asserted interest.").

${ }^{159}$ Village of Schaumburg $v$ Citizens for a Better Environment, 444 US 620, 636-37 (1980) ("The [state] may serve its legitimate interests, but it must do so by narrowly drawn regulations designed to serve those interests without unnecessarily interfering with First Amendment freedoms."); United States v O'Brien, 391 US 367, 376-77 (1968) (describing the four-part intermediate scrutiny test).

${ }^{160}$ Shelton v Tucker, 364 US 479, 488 (1960). See also Citizens for a Better Environment, 444 US at 636 (holding restriction invalid if purpose "could be sufficiently served by measures less destructive of First Amendment interests").

${ }_{161}$ Primus, 436 US 412, 427-28 (1978) (holding that ACLU litigation in support of civil liberties is analogous to NAACP activities in Button and constitutes a form of political 
cal Bank, the named plaintiffs brought a Rule 23(b)(2) action against a bank alleging discriminatory employment practices. ${ }^{162}$ Before the class was certified, the plaintiffs moved for approval of a settlement agreement. ${ }^{163}$ The court ordered notice of the proposed settlement for each purported class member, advising each of his or her rights, as required by Rule 23(e). The court also permitted class members to opt out of the settlement agreement, ${ }^{164}$ which Rule 23(e) does not require.

Of the approximately five hundred class members in Plummer, twenty-five opted out. ${ }^{165}$ Among those who opted out, eight asserted that they had not been discriminated against by the bank. ${ }^{166}$ For these eight, then, participation in the class action would have violated their right of political expression and association because their cause of action-a property right-would have been used to assert claims of discrimination. The First Amendment opt-out right is particularly important in such a suit. Although the parties are pursuing constitutionally protected civil liberties, reasonable people can disagree whether these liberties were infringed. Note that, had the case gone to trial, class members who did not believe they were discriminated against would have been unable to opt out. ${ }^{167}$

We can also envision a hypothetical case in which the numbers differ from those in Plummer. For example, imagine that the number of class members who chose to opt out because they believed they were not discriminated against was much higher, say four hundred out of five hundred class members. In such a case, the significance of mandatory participation, and the inherent compelled contribution, becomes even more clear. If the class attorneys required a minimum of two hundred individual claims to make litigation of the case financially viable, and if parties were free to opt out, the case would collapse. Here, mandatory class membership would force people to "contribute" to the suit

association). Compare Ohralik v Ohio State Bar Association, 436 US 447, 458 (1978), quoting Button, 371 US at 442 (explaining that Ohralik was not governed by Button or Primus because solicitation of litigation for personal injury case did not involve "political expression or an exercise of associational freedom ... 'to secure constitutionally guaranteed civil rights").

${ }_{152} 668$ F2d 654, 656 (2d Cir 1982).

tos Plummer $v$ Chemical Bank, 91 FRD 434, 436 (S D NY 1981), aff'd, 668 F2d 654.

res Id.

105 Id.

${ }^{165}$ Plummer, $668 \mathrm{~F} 2 \mathrm{~d}$ at $657 \mathrm{n} 3$.

167 See FRCP 23(c)(3). 
against their will, facilitating political expression with which they disagree. ${ }^{168}$

This Comment does not belittle the interests favoring mandatory class certification in a case such as Plummer. But, where litigation pursues civil liberties or political ends, the First Amendment right of a dissenter to be free from compelled expression and association (through a compelled contribution to the suit) outweighs those interests. In such a case, the right to opt out must be unfettered.

\section{B. A Limited Right to Opt Out of Commercial Class Actions}

For regulations of commercial expression to withstand intermediate scrutiny, they must satisfy a four-part test. ${ }^{169}$ First, the activity must invoke constitutional protection. ${ }^{170}$ Section II demonstrated that compelled participation in a class action is protected by the First Amendment. Second, the state interests must be substantial. ${ }^{171}$ Although the analysis in Section III.B questions whether the state's interests in the class action context are compelling, they could fairly be considered substantial. Next, a court must determine whether the "regulation directly advances the governmental interest asserted, and whether it is not more extensive than is necessary to serve that interest."172 Another example helps to demonstrate the First Amendment interests at stake in a class action and shows that the state can indeed regulate such activity more narrowly than it currently does.

In Brown v Ticor Title Insurance Co., class plaintiffs alleged that Ticor and others had conspired to fix prices for title search and examination services through state-licensed rate-making

${ }^{169}$ Note that the Supreme Court recently decided, unanimously, in favor of a petitioner making the mirror image of this Comment's argument. See Hurley $v$ Irish-American Gay, Lesbian and Bisexual Group of Boston, 115 S Ct 2338, 2348 (1995) (holding that because the First Amendment protects the "autonomy to control one's own speech," it thus permits a parade organizer to deny a gay group participation because "it boils down to the choice of a speaker not to propound a particular point of view, and that choice is presumed to lie beyond the government's power to control"). See also New York County Board of Ancient Order of Hibernians $v$ Dinkins, 814 F Supp 358, 366 (S D NY 1993) ("[T]he message intended to be conveyed by a parade sponsored by a private organization is to be determined by the parade sponsor and not by the state."); Invisible Empire of the Knights of the Ku Klux Klan $v$ Town of Thurmont, 700 F Supp 281, 287-88 (D Md 1988) (holding that allowing blacks to march in KKKK parade, against parade organizer's wishes, violated Klan's right to symbolic speech).

${ }^{169}$ Central Hudson Gas \& Elec. Corp v Public Serv. Comm'n, 447 US 557, 566 (1980).

170 Id.

171 Id.

172 Id. 
bureaus. ${ }^{173}$ While the case was pending, the Supreme Court decided a related case $\mathrm{e}^{174}$ that weakened the class plaintiffs' claims. As a result, the plaintiffs negotiated a settlement with Ticor that disposed of their damages claims. ${ }^{175}$

Several class members filed motions opposing the settlement; the district judge rejected these opt-out claims. ${ }^{176}$ The class members appealed the decision, and the Court of Appeals affirmed without opinion. ${ }^{177}$ Two class members then filed suit against Ticor in two different state courts, asserting the same claims originally in dispute. ${ }^{178}$ The state courts dismissed both suits without considering the substantive issue. ${ }^{179}$ Class members then filed suit in federal court in another state; that suit was dismissed as res judicata. ${ }^{180}$ The Ninth Circuit reversed the dismissal, holding that the class members had a due process right to opt out of the original settlement agreement. ${ }^{181}$

A First Amendment analysis of this case would recognize that the plaintiffs were suing to enforce commercial rights, or pursuing commercial goals; they were seeking damages for price fixing. Because the action was pursuing nonpolitical goals, the individual's constitutional interest in freedom from coerced expression or support of the litigation was less weighty. ${ }^{182}$ An absent class member should receive the right to opt out of such a case only when the goals for which the class was initially certified no longer comport with the intended actions of the class representatives:

The furtherance of the common cause leaves some leeway for the leadership of the group. As long as they act to promote

173982 F2d 386, 390 (9th Cir 1992), cert dismissed as improvidently granted, $114 \mathrm{~S} \mathrm{Ct}$ 1359 (1994). See also In re Real Estate Title \& Settlement Serv. Antitrust Litig., 1986-1 Trade Cases (CCH) II 67,149 at 62,921 (E D Pa 1986).

${ }^{174}$ Southern Motor Carriers Rate Conference, Inc. v United States, 471 US 48 (1985) (redefining how the state action doctrine should apply to state-licensed rate-making bureaus).

175 In re Real Estate, 1986-1 Trade Cases II 67,149 at 62,923-25.

176 Id at 62,925-26.

177 In re Real Estate Title \& Settlement Serv. Antitrust Litig., 815 F2d 695 (3d Cir 1987).

${ }_{17}$ See generally Tucson Unified School District $v$ Chicago Title Insurance Co., 167 Ariz 114, 804 P2d 843 (Ariz Ct App 1991); Prentice $v$ Title Insurance Co., 174 Wis 2d 714, 500 NW2d 658 (1993), cert denied 114 S Ct 1058 (1994).

${ }_{179}$ Tucson Unified School District, 804 P2d at 845; Prentice, 500 NW2d at 660.

so See Brown, 982 F2d at 387.

Idr Id at 392.

${ }^{162}$ See Riley, 487 US at 796 n 9 ("Purely commercial speech is more susceptible to compelled disclosure requirements."). 
the cause which justified bringing the group together, the individual cannot withdraw his financial support merely because he disagrees with the group's strategy. ${ }^{183}$

The Third Circuit, in affirming the first district court's rejection of the original opt-out claims, made essentially the same determination when it held that the settlement agreement "involved the foreclosure of substantial damage claims." soning, the Ninth Circuit held that there was a right to opt out. ${ }^{185}$ While the Ninth Circuit made its decision on due process grounds, a First Amendment analysis would have reached the same result and provided a complementary, yet more solid, foundation for the decision.

Thus, recognizing a First Amendment-based right to opt out of mandatory class actions seeking "commercial" ends would permit dissenters to opt out when the suit no longer serves the purposes, goals, or legal remedies of the suit, as understood when the class originally received certification. This approach would require an assessment by the court of whether members' opt-out rights should vest whenever the class representatives choose a course of action seemingly inconsistent with the suit's original goals.

\section{CONCLUSION}

It is likely that the Supreme Court will address the constitutional basis of class actions and the breadth of the right to opt out in the near future; doing so could eliminate confusion in existing jurisprudence. Nonetheless, a constitutional right to opt out founded on the First Amendment is potentially broader, and certainly sounder, than one based on due process. The basis for such a right exists in current jurisprudence and the state's interests are insufficiently compelling on their face to preclude review toward this end.

Even if the current regime of mandatory class certification contributes to efficient and fair litigation, those benefits do not offset the risk that mandatory class actions will coerce individuals into supporting political goals inconsistent with their beliefs.

${ }^{183}$ Abood, 431 US at 222-23, quoting International Association of Machinists $v$ Street, 367 US 740, 778 (1961).

${ }_{184}$ In re Real Estate Title \& Settlement Serv. Antitrust Litig., 869 F2d 760, 768 (3d Cir 1989).

${ }^{185}$ Brown, 982 F2d at 392. 
Compelled membership in class actions results in coerced, tangible support for the goals of litigation. This implicates fundamental First Amendment liberties. Absent narrowly drawn limitations in support of compelling governmental interests, mandatory class actions can result in unconstitutionally coerced expression and association.

A better solution would consider class actions in light of First Amendment interests. A new right to opt out for individual class members should arise where a suit pursues political ends or goals. In nonpolitical or commercial suits, the First Amendment would recognize - as did the Ninth Circuit's due process-based analysis in Brown-a right to opt out when a class action no longer promotes the goals or legal remedies for which it was certified. This more narrowly drawn alternative serves the state's interest in allowing litigation through the mandatory class action device, while preserving individual First Amendment liberties. 


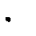

